\title{
Production, Purification and Characterization of Inulinase from a Newly Isolated Streptomyces sp. CP01
}

\author{
Nirobol Laowklom, Rungtrakarn Chantanaphan, Pairoh Pinphanichakarn
}

Department of Microbiology, Faculty of Science, Chulalongkorn University, Bangkok, Thailand.

Email: Pairoh.P@Chula.ac.th

Received March $6^{\text {th }}, 2012$; revised April $9^{\text {th }}, 2012$; accepted April 23 ${ }^{\text {rd }}, 2012$

\begin{abstract}
Inulinase is an enzyme catalyzing the hydrolysis of inulin, a plant reserve polysaccharide, into fructoses and fructooligosaccharides which are widely used as food additives. Here we report inulinase from a newly isolated Streptomyces as in the past decade there have been very few reports on inulinases from Streptomyces, especially purification and characterization of these enzymes. Out of 371 Streptomyces isolates, Streptomyces sp. CP01 produced highest inulinase activity of $0.50 \mathrm{U} / \mathrm{ml}$. The enzyme activity was increased to $1.60 \mathrm{U} / \mathrm{ml}$ when CP01 was cultivated under the optimal conditions which consisted of using basal medium (Czapek's Dox) containing 1\% (w/v) inulin extract from Jerusalem artichoke's root tubers and $0.7 \%(\mathrm{w} / \mathrm{v})$ tryptone at $\mathrm{pH} 8$, shaking at $200 \mathrm{rpm}$ and $28^{\circ} \mathrm{C}$ for $24 \mathrm{~h}$. The enzyme was purified from culture filtrate to about 67 -fold purity by $\left(\mathrm{NH}_{4}\right)_{2} \mathrm{SO}_{4}$ precipitation followed by four consecutive column chromatography steps. The purified enzyme is a single peptide with approximate molecular mass of $73 \mathrm{kDa}$ as analyzed by gel filtration and $70.8 \mathrm{kDa}$ as assessed by SDS-PAGE. The enzyme is optimally active at $55^{\circ} \mathrm{C}$ and $\mathrm{pH} 6.0$, however it still possesses more than $80 \%$ of the maximal activity at $\mathrm{pH}$ ranging from 5.5 to 9.0 . It is stable at temperature up to $50^{\circ} \mathrm{C}$ and at broad range of $\mathrm{pH}$ from 5.0 to 9.0 for $30 \mathrm{~min}$. Its $K_{m}$ and $V_{\max }$ values for inulin were $2.34 \mathrm{mM}$ and 440 $\mu \mathrm{mol} \cdot \mathrm{min}^{-1} \cdot \mathrm{mg}^{-1}$, respectively. This enzyme has potential for industrial application as it is active at moderately high temperature and wide range of $\mathrm{pH}$.
\end{abstract}

Keywords: Characterization; Inulinase; Production; Purification; Streptomyces

\section{Introduction}

Inulin is a polyfructan in plant consisting of linear chains $\beta$-(2,1)-linked fructose residues attached to a terminal sucrose molecule [1]. It is a reserve as a storage carbohydrate and accumulated in the underground organ of several plants such as Jerusalem artichoke (Helianthus tuberosus), chicory (Cichorium intibus), dahlia (Dahlia pintana) and dandelion (Taraxacum officinal) $[2,3]$. As it is abundantly available in nature and having fructose as its major composition, therefore it is suitable to be used as a substrate for fructo-oligosaccharides and high fructose syrup production for food, drink and pharmaceutical industries [4]. Moreover, fructose is also used as a substrate for bioethanol fermentation as renewable energy source by Saccharomyces cerevisiae and Zymomonas mobilis [5].

There have been reports of inulinase, an enzyme catalyzing the hydrolysis of inulin, from many microorganisms including Aspergillus niger NK-126, Kluyveromyces marxianus YS-1, Bacillus smithii T7, Kluyveromyces sp. Y-85, a mutant of the marine yeast Pichia guilliermondii, Staphylococcus sp. and Kluyveromyces marx- ianus ATCC 52466 [6-11]. However, there was only few reports on inulinases from Streptomyces [12,13]. It is well known that several Streptomyces species produce a great variety of useful bioactive metabolites, including antibiotics, anticancer agents, insecticides, enzyme inhibitors and industrial important enzymes. Streptomyces species are soil bacteria found in different environments around the world, thus the enzymes produced by these microorganisms should be active under various environments corresponding to the habitats where they are isolated. Here, we report isolation of Streptomyces from Thai-soil which is located in the tropical zone and screening for inulinase-producing ability of the isolates. Optimization of inulinase-production by the selected strain, purification and characterization of the enzyme are also included.

\section{Materials and Methods}

\subsection{Materials}

Inulin from chicory root was purchased from SigmaAldrich (Saint Loius, MO). The chromatography unit used for protein purification was the model Bio-Logic LP 
and slab gel electrophoresis set was the model MiniProtein II Dual, both were from Bio-Rad Laboratories (Hercules, CA).

\subsection{Isolation of Streptomyces and Screening for Inulinase-Producing Strains}

Soil samples were collected from garlic-, onion- and $J e-$ rusalem artichoke-plantations. The samples were suspended in sterile distilled water $(1 \mathrm{~g}$ in $10 \mathrm{ml})$, serially diluted up to $10^{-4}$ and spread $(0.1 \mathrm{ml})$ onto selective humic acid-vitamin agar medium as described by Hayakawa and Nonomura [14] and then incubated at $30^{\circ} \mathrm{C}$ for 5 - 7 days. Representative colonies were picked up and isolated to pure cultures using Bennett agar medium. The pure isolates were stored at $-20^{\circ} \mathrm{C}$ as spore suspension in sterile $30 \%(\mathrm{~V} / \mathrm{V})$ glycerol prepared according to Kieser, et al. [15].

To screen for inulinase-producing isolates, spore suspension $\left(100 \mu 1,10^{8}\right.$ spores $\left./ \mathrm{ml}\right)$ was inoculated into 30 ml-Luria broth and pregerminated at $30^{\circ} \mathrm{C}$ for $24 \mathrm{~h}$ with shaking at $200 \mathrm{rpm}$ and used as a seed culture. The seed culture $(10 \%, \mathrm{~V} / \mathrm{V})$ was inoculated into the basal medium (Czapek's Dox medium) contained $\left(\mathrm{gl}^{-1}\right)$ : $\mathrm{NaNO}_{3}, 3.0$; $\mathrm{K}_{2} \mathrm{HPO}_{4}, 1.0 ; \mathrm{MgSO}_{4} \cdot 7 \mathrm{H}_{2} \mathrm{O}, 0.5 ; \mathrm{KCl}, 0.5 ; \mathrm{FeSO}_{4} \cdot 7 \mathrm{H}_{2} \mathrm{O}$ and $1 \%$ inulin, $\mathrm{pH} 5.0$ and incubated with shaking at 200 $\mathrm{rpm}$ at $30^{\circ} \mathrm{C}$ for 3 days. After that the mycelium was removed by centrifugation at $8000 \mathrm{rpm}$ for $10 \mathrm{~min}$ and the culture supernatant was assayed for inulinase activity as described by Sharma and Gill [16] in which the reaction was performed at $\mathrm{pH} 6.0$ and $60^{\circ} \mathrm{C}$.

\subsection{Cultivation of Streptomyces sp. CP01 and Strain Identification}

Streptomyces sp. CP01, a selected inulinase-producing strain isolated from Jerusalem artichoke-grown soil, was used for inulinase production. Seed culture for inulinase production was prepared by inoculating $100 \mu \mathrm{l}$ of spore suspension (approx. $10^{8}$ spores $/ \mathrm{ml}$ ) in $30 \mathrm{ml}$-Luria broth medium and incubating at $30^{\circ} \mathrm{C}$ with shaking at $200 \mathrm{rpm}$ for $24 \mathrm{~h}$. Ten percent $(\mathrm{V} / \mathrm{V})$ of the seed culture was inoculated into basal medium containing different carbon or nitrogen sources as indicated in the results and cultivated under the same conditions as those of the seed culture or otherwise indicated.

For strain identification, its $16 \mathrm{~S}$ rDNA gene was amplified using the primers described by Kataoka, et al. [17]. Direct sequencing of the PCR product was performed by Macrogen (Korea) and the sequence was compared with those retrieved from the GenBank data base.

\subsection{Preparation of Crude Inulin Extract from Jerusalem artichoke}

Jerusalem artichoke's root tubers were obtained locally.
After washing, they were sliced, dried and ground into powder. The inulin extract was prepared as described by Singh, et al. [7] by suspending the powder in distilled water $(10 \%, \mathrm{~W} / \mathrm{V})$ then boiled under pressure at $15 \mathrm{psi}$ for $10 \mathrm{~min}$. After that it was filtered through muslin cloth, centrifuged at $8000 \mathrm{rpm}$ for $10 \mathrm{~min}$ and used as the crude inulin extract. The inulin content was determined as described by Lingyun, et al. [18].

\subsection{Enzyme Assay}

Inulinase activity was determined as described by Sharma and Gill [16] with minor modification. The reaction mixture containing $50 \mu \mathrm{l}$ of enzyme sample, $55 \mu 1$ of $50 \mathrm{mM}$ sodium phosphate buffer $\mathrm{pH} 6.0$ and $95 \mu \mathrm{l}$ of $1 \%$ inulin suspended in $50 \mathrm{mM}$ sodium phosphate buffer $\mathrm{pH} 6.0$ was incubated at $55^{\circ} \mathrm{C}$ for $20 \mathrm{~min}$. After that the reaction mixture was kept in ice bath for 5 min to inactivate the enzyme. The reducing sugars produced were determined by the DNSA method [19]. One unit of inulinase was defined as the amount of enzyme that produced one micromole of reducing sugar per minute under the assay conditions.

\subsection{Enzyme Purification}

CP01 was cultivated under the optimal conditions for inulinase production, after that the mycelium was removed by centrifugation at $8000 \mathrm{rpm}$ for $15 \mathrm{~min}$ and the culture supernatant was used as the crude enzyme. All steps of the enzyme purification were done at $4^{\circ} \mathrm{C}$. The crude enzyme was first fractionated by ammonium sulfate precipitation $(40 \%-80 \%$ saturation) followed by dialysis against sodium-phosphate buffer $\mathrm{pH}$ 6.0, concentrated by dehydrating with Blanose CMC12M31P (Ashland Aqualon) and then applied onto a Macro-Prep DEAE column $(1.5 \times 30 \mathrm{~cm})$ pre-equilibrated with $50 \mathrm{mM}$ tris- $\mathrm{HCl}$ buffer $\mathrm{pH}$ 7.5. The adsorbed proteins were eluted with a linear gradient of $\mathrm{NaCl}(0-1 \mathrm{M})$ in the same buffer at a flow rate of $0.5 \mathrm{ml} / \mathrm{min}$. The fractions showing inulinase activity were pooled and dialyzed overnight against 50 $\mathrm{mM}$ sodium-phosphate buffer $\mathrm{pH} 6.0$ and concentrated as above. It was then loaded on Sephacryl S-200 column $(1 \times$ $30 \mathrm{~cm}$ ) prior equilibrated with $50 \mathrm{mM}$ sodium-phosphate buffer $\mathrm{pH}$ 6.0. The column was eluted with the same buffer at a flow rate of $0.12 \mathrm{ml} / \mathrm{min}$. The fractions showing enzyme activity were pooled and concentrated as above and loaded onto t-butyl hydrophobic interaction column $(0.8 \times 10 \mathrm{~cm})$ prior equilibrated with $50 \mathrm{mM}$ sodium-phosphate buffer $\mathrm{pH} 6.0$ containing $1.7 \mathrm{M}$ ammonium sulfate.

\subsection{Protein Content}

Protein content was determined by the Lowry method [20] using bovine serum albumin as a standard. 


\subsection{Enzyme Characterization and Kinetics}

For determination of the optimum temperature and $\mathrm{pH}$ on enzyme activity, the activity was first determined under the standard conditions, from $30^{\circ} \mathrm{C}$ to $80^{\circ} \mathrm{C}$. Enzyme activity was then determined at different $\mathrm{pH}$ values ranging from 4.0 to 9.0 at the assessed optimal temperature.

For determination of thermal and $\mathrm{pH}$ stability, the enzyme was pre-incubated in the absence of substrate at different temperatures, ranging from $30^{\circ} \mathrm{C}$ to $90^{\circ} \mathrm{C}$, or at different $\mathrm{pH}$ values ranging from $4.0^{\circ} \mathrm{C}$ to $9.0^{\circ} \mathrm{C}$ at $55^{\circ} \mathrm{C}$ for $30 \mathrm{~min}$ and the remaining activity was determined under the standard conditions and reported as relative activity of pretreated enzyme.

For the influence of metal ions, the enzyme was pretreated with EDTA by dialyzing overnight against 100 $\mathrm{mM}$ EDTA in $50 \mathrm{mM}$ sodium phosphate buffer (pH 6.0), and after that it was dialyzed twice against the same buffer without EDTA. The effect of metal ions was assessed by pre-incubating the enzyme with the test compound at $0^{\circ} \mathrm{C}$ for $30 \mathrm{~min}$ and then assaying the residual enzymatic activity under standard conditions. The Michaelis-Menten kinetic parameters $K_{m}$ and $V_{\max }$ were determined from Lineweaver-Burk plots using inulin from chicory root and sucrose at concentrations ranging from 0.5 to $2.0 \mathrm{mM}$ and 20 to $200 \mathrm{mM}$, respectively, as substrate.

\subsection{Molecular Weight Determination}

The molecular weight of the purified inulinase was determined by gel filtration chromatography on a Sephacryl S-200 HR column $(1 \times 50 \mathrm{~cm})$ at a flow rate of 7.2 $\mathrm{ml} \cdot \mathrm{h}^{-1}$ using catalase $(250 \mathrm{kDa})$ globulin $(150 \mathrm{kDa})$ and bovie serum albumin $(66 \mathrm{kDa})$ as molecular weight standards. Subunit molecular weight was determined by sodium dodecyl sulfate-polyacrylamide gel electrophoresis (SDS-PAGE), as described by Laemmli [21], on a $12 \%(\mathrm{~W} / \mathrm{V})$ polyacrylamide gel.

\section{Results and Discussion}

\subsection{Isolation of Streptomyces and Screening for Inulinase-Producing Isolates}

From 371 isolates, Streptomyces strain CP01 was found to have highest inulinase activity of $0.50 \mathrm{U} / \mathrm{ml}$ under screening conditions. This level was comparable to those reported from the other Streptomyces which were grown under their optimal conditions including Streptomyces sp. GNDU1 $(0.55 \mathrm{U} / \mathrm{ml})$ [13] and Streptomyces sp. isolated from chicory root $(0.52 \mathrm{U} / \mathrm{ml})$ [12]. Streptomyces sp. CP01 was therefore selected for further study on inulinase production. This selected isolate was identified by analyzing its $16 \mathrm{~S}$ rRNA gene sequence comparing to those retrieved from the GenBank data base (data not shown). The results indicated that CP01 was closely related to Streptomyces griseoruber with $99.343 \%$ similarity. This $16 \mathrm{~S}$ rRNA gene sequence was deposited in GenBank under accession number GU458298.

\subsection{Optimization for Inulinase Production by Streptomyces sp. CP01}

Different carbon compounds including sucrose, glucose, fructose, maltose, manitol, pure inulin from chicory root and the inulin extract prepared as described in materials and methods were tested as a carbon source for inulinase production by CP01 grown in the basal medium for $24 \mathrm{~h}$. As shown in Figure 1, inulin was the best carbon source for inulinase production yielding the maximum enzyme activities of about $0.55 \mathrm{U} / \mathrm{ml}$ with pure inulin and about $0.85 \mathrm{U} / \mathrm{ml}$ with the inulin extract at $1 \%(\mathrm{~W} / \mathrm{V})$. This finding was in agreement with Pandey, et al. [22] who found that inulin-containing plant materials were superior to pure substrates for inulinase production. Inulin has also been reported to be the best carbon source for the production of inulinases from various microorganisms including Kluyveromyces marxianus YS-1 [7], Kluyveromyces marxianus DSM 70106 [23], Kluyveromyces marxianus var. bulgaricus [24], Bacillus smithii T7 [8] and Cryptococcus aureus G7a [25].

Effect of nitrogen source on the enzyme production was performed by cultivating $\mathrm{CP} 01$ in the basal medium containing $1 \%$ inulin extract and $0.3 \%(\mathrm{w} / \mathrm{v})$ of different nitrogen sources. Similar to Thielaria terrestris NRRL 8126 and Aspergillus foetidus NRRL 337 reported by Fawzi [26], tryptone was found to be the best nitrogen source for inulinase production and the optimal concentration for $\mathrm{CP} 01$ was obtained at $0.7 \%(\mathrm{~W} / \mathrm{V})$ yielding inulinase activity of about $1.3 \mathrm{U} / \mathrm{ml}$ (Figure 2).

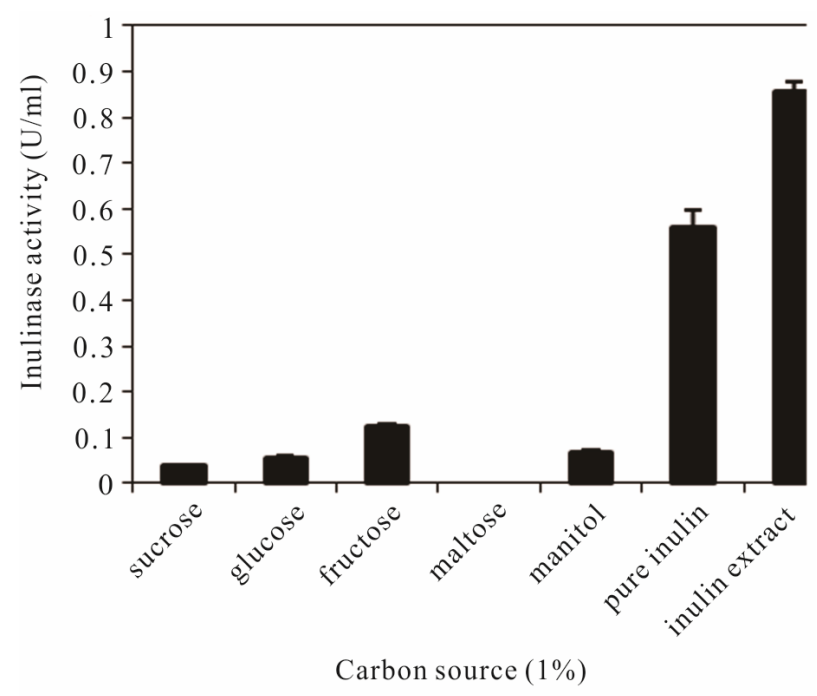

Figure 1. Effects of carbon sources on inulinase production by CP01. 
Effects of $\mathrm{pH}$ and temperature on inulinase production were also assessed and found that the optimal $\mathrm{pH}$ and temperature were $\mathrm{pH} 8.0$ and $28^{\circ} \mathrm{C}$, respectively (Figure 3). Under these conditions inulinase activity of about 1.6 $\mathrm{U} / \mathrm{ml}$ which was about 3 -fold higher than that of the screening conditions was obtained. This finding indicated that CP01 was the most potent inulinase-producer among Streptomyces ever reported so far.

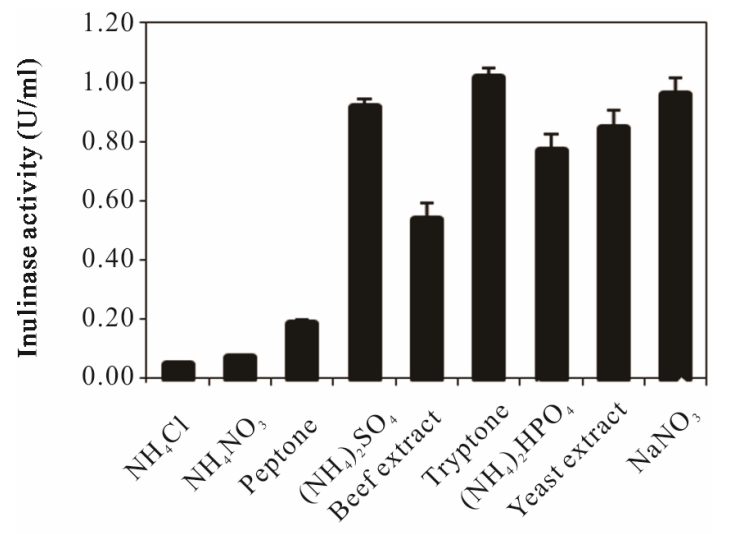

Nitrogen source $(0.3 \%$, w/v)

(a)

\subsection{Purification, Molecular Characteristics and Properties of Inulinase}

Inulinase from Streptomyces sp. CP01 was purified to homogeneity with about 67 fold-purity by fractionation with ammonium sulfate followed by four steps of column chromatography (Table 1). The enzyme had molecular mass of approximately $73 \mathrm{kDa}$ estimated by gel filtration

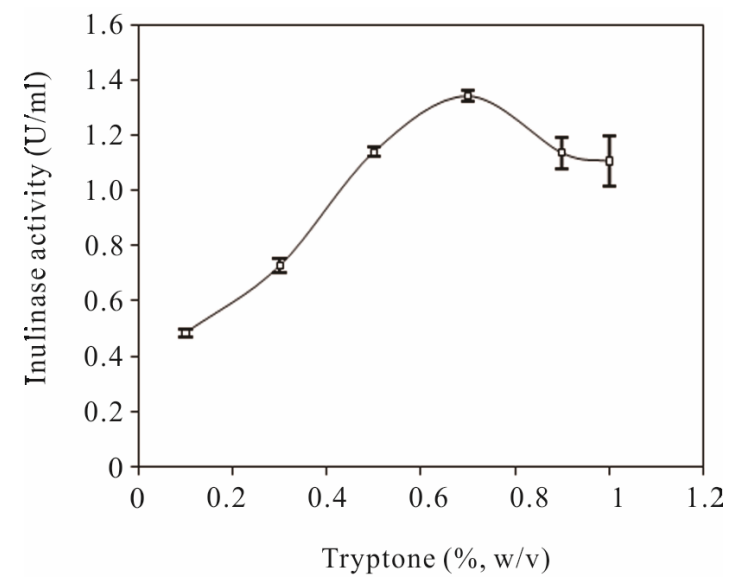

(b)

Figure 2. Effect of (a) nitrogen source and (b) concentration of tryptone on inulinase production.

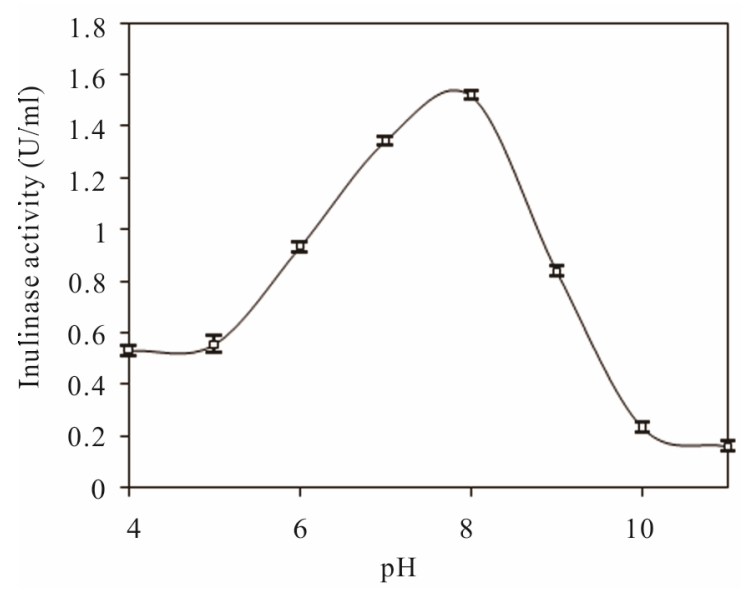

(a)

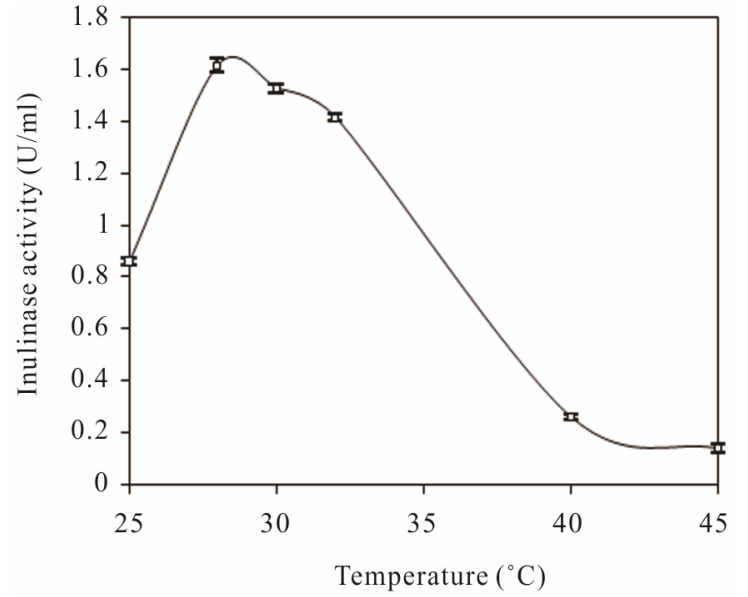

(b)

Figure 3. Effects of (a) initial pH and (b) cultivation temperature on inulinase production.

Table 1. Purification of inulinase from Streptomyces sp. CP01.

\begin{tabular}{|c|c|c|c|c|c|}
\hline Step of purification & Total activity (U) & Total protein $(\mathrm{mg})$ & $\begin{array}{c}\text { Specific activity } \\
\left(\mathrm{U} \cdot \mathrm{mg}^{-1}\right)\end{array}$ & Yield (\%) & Purification (fold) \\
\hline Culture supernatant & 1278.0 & 294.4 & 4.3 & 100.0 & 1.0 \\
\hline $\begin{array}{l}\text { Ammonium sulfate precipitation } \\
(40 \%-80 \% \text { saturation })\end{array}$ & 809.9 & 67.5 & 12.00 & 63.4 & 2.8 \\
\hline Macro-Prep DEAE & 404.4 & 4.9 & 83.0 & 31.6 & 19.1 \\
\hline Sephacryl S-200 & 172.7 & 1.0 & 167.7 & 13.5 & 38.6 \\
\hline t-Butyl hydrophobic interaction & 69.4 & 0.4 & 192.2 & 5.4 & 44.4 \\
\hline Hydroxyapatite & 23.2 & 0.08 & 290.2 & 1.8 & 66.9 \\
\hline
\end{tabular}


on Sephacryl S-200 (data not shown) and $70.8 \mathrm{kDa}$ analyzed by SDS-PAGE (Figure 4). These values were different from that of the inulinase from Streptomyces $\mathrm{sp}$. (45 kDa) [16]. The enzyme had optimal activity at $55^{\circ} \mathrm{C}$ and was stable at temperature up to 50 and still retained about $80 \%$ of its activity at $55^{\circ} \mathrm{C}$ (Figure 5). It is considered to be active at moderately high temperature when compared to those of the other inulinases such as from Aspergillus niger Mutant $817\left(40^{\circ} \mathrm{C}\right)$ [27], Bacillus polymyxa $\left(35^{\circ} \mathrm{C}\right)[28]$ and Cryptococcus aureus $\mathrm{G} 7 \mathrm{a}\left(50{ }^{\circ} \mathrm{C}\right)$ [25]. The enzyme had optimal $\mathrm{pH}$ of 6.0 , however it was still quite active at broad $\mathrm{pH}$ range from 5.5 to 9.0 and stable at broad range of $\mathrm{pH}$ from 5.0 to 9.0 for $30 \mathrm{~min}$ (Figure 6) whereas inulinases from many microorganisms were reported to be optimally active at acid $\mathrm{pH}$ including Aspergillus niger Mutant 817 (pH 5.0) [27], Bacillus smithii $\mathrm{T} 7$ ( $\mathrm{pH} 4.5)$ [8] Kluyveromyces marxianus var. bulgaricus (pH 4.75) [29] and Fusarium oxysporum (pH 4.0 - 5.5) [30].

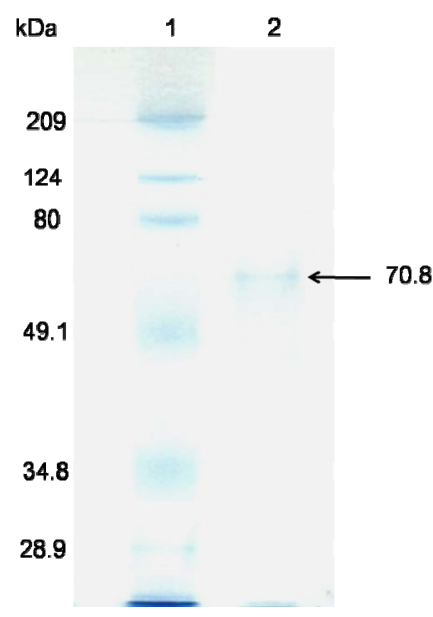

Figure 4. SDS-PAGE of the purified inulinase. Lane 1, prestained SDS-PAGE standards (catalog\# 161-0318 from Bio-Rad Laboratories); Myosin (209 kDa), $\beta$-galactosidase (124 kDa), Bovine serum albumin (80 kDa), Ovalbumin (49.1 kDa), carbonic anhydrase (34.8 kDa), Soybean trypsin inhibitor (28.9 kDa); Lane 2, the purified inulinase $(\leftarrow)$.

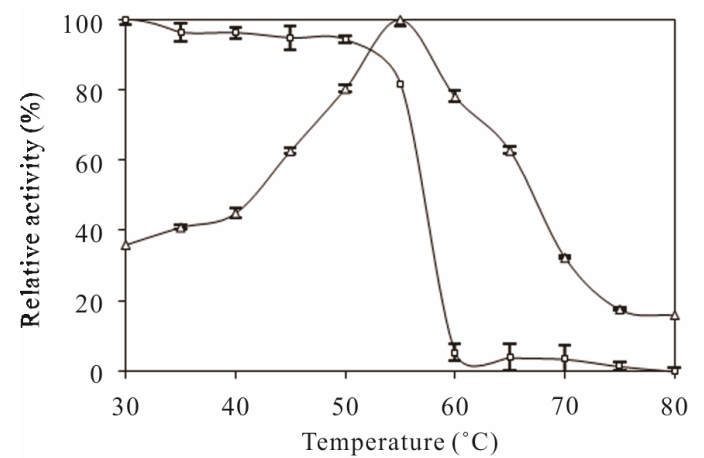

Figure 5. Effect of temperature on activity $(\Delta)$ and stability ( $\square$ ) of the enzyme.
For substrate specificity, its $K_{m}$ and $V_{\max }$ values for inulin were $2.34 \mathrm{mM}$ and $440 \mu \mathrm{mol} \mathrm{min}{ }^{-1} \cdot \mathrm{mg}^{-1}$, respectively and for sucrose were $40 \mathrm{mM}$ and $12.31 \mu \mathrm{mol}$ $\min ^{-1} \cdot \mathrm{mg}^{-1}$, respectively. Its $K_{m}$ value for inulin was lower than those from Bacillus smithii T7 (4.17 mM) [8] and Kluyveromyces marxianus var.bulgaricus (11.9 mM) [29] while its $K_{m}$ value for sucrose was closely similar to that of Kluyveromyces marxianus CDBB-L-278 (40.18 $\mathrm{mM}$ ) [31].

We also assessed the effect of metal ions on inulinase activity. We found that $\mathrm{Hg}^{2+}$, the typical inhibitor of most enzymes, was the most potent inhibitor, whereas $\mathrm{Mg}^{2+}$, $\mathrm{Mn}^{2+}$ and $\mathrm{Co}^{2+}$ strongly activated the enzyme activity (Table 2). There have been reports that $\mathrm{Mn}^{2+}$ and $\mathrm{Co}^{2+}$ activated the activity of inulinases from Aspergillus niger Mutant 817 [27], Kluyveromyces marxianus YS-1 [32] and Streptomyces sp. [16]. It was also found that, $\mathrm{Cu}^{2+}$ slightly activated inulinase from $\mathrm{CP} 01$ while $\mathrm{Fe}^{2+}, \mathrm{Zn}^{2+}$ and $\mathrm{Ca}^{2+}$ had slight inhibitory effect. This is in contrast to inulinases from many microorganisms which were strongly inhibited by more variety of metal ions such as inulinase from Kluyveromyces marxianus YS-1 was inhibited by

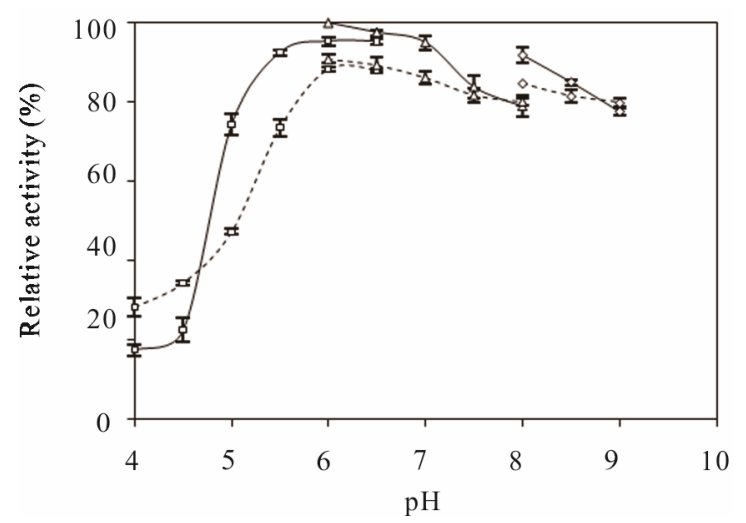

Figure 6. Effect of pH on activity (-) and stability (- - ) of the enzyme. $(\square), 50 \mathrm{mM}$ sodium acetate buffer; $(\Delta), 50 \mathrm{mM}$ sodium phosphate buffer; $(\diamond), 50 \mathrm{mM}$ tris-HCl buffer.

Table 2. Effects of various metal ions on inulinase activity.

\begin{tabular}{lc}
\hline Ion $(1 \mathrm{mM})$ & Relative activity ${ }^{\mathrm{a}}(\%)$ \\
\hline $\mathrm{None}$ & 100 \\
$\mathrm{MgSO}_{4} \cdot 7 \mathrm{H}_{2} \mathrm{O}$ & 113 \\
$\mathrm{FeSO}_{4} \cdot 7 \mathrm{H}_{2} \mathrm{O}$ & 88 \\
$\mathrm{CuSO}_{4} \cdot 5 \mathrm{H}_{2} \mathrm{O}$ & 105 \\
$\mathrm{CoCl}_{2} \cdot 6 \mathrm{H}_{2} \mathrm{O}$ & 128 \\
$\mathrm{ZnSO}_{4} \cdot 7 \mathrm{H}_{2} \mathrm{O}$ & 88 \\
$\mathrm{MnSO}_{4} \cdot \mathrm{H}_{2} \mathrm{O}$ & 159 \\
$\mathrm{CaCl}_{2} \cdot 5 \mathrm{H}_{2} \mathrm{O}$ & 98 \\
$\mathrm{HgCl}_{2}$ & 8 \\
\hline
\end{tabular}

${ }^{a}$ Relative activities were calculated in relation to the enzyme activity without ion, which was considered to be $100 \%$. 
$\mathrm{Cu}^{2+}, \mathrm{Mg}^{2+} \mathrm{Zn}^{2+}$ and $\mathrm{Ca}^{2+}[32]$ while that from Rhizoctonia solani was inhibited by $\mathrm{Fe}^{2+}, \mathrm{Zn}^{2+}, \mathrm{Mg}^{2+}, \mathrm{Mn}^{2+}[33]$ and inulinase from Aspergillus fumigatus was inhibited by $\mathrm{Fe}^{2+}, \mathrm{Zn}^{2+}$ and $\mathrm{Co}^{2+}[34]$. As only few metal ions have inhibitory effect on inulinase from CP01, this enzyme is considered to have superior properties.

The amino acid modifying agents ethylmethylaminopropyl carbodiimide and phenylmethylsulfonyl fluoride had little effect on enzyme activity even at concentrations as high as $10 \mathrm{mM}$. However, the enzyme was completely inhibited by $1 \mathrm{mM} \mathrm{N}$-bromosuccinimide and the activity was reduced about $40 \%$ by $10 \mathrm{mM}$ iodoacetamide (Table 3) suggesting tryptophan and cysteine residues are involved in catalytic activity and tryptophan might play the most important role. There have been reports that tryptophan is important for catalytic activity of inulinases from Aspergillus niger Mutant 817 [27] and Penicillium sp. TN-88 [35] whereas cysteine is important for inulinases from Cryptococcus aureus G7a [36] and Pichia guilliermondii [37].

Further characterization of inulinase from CP01 by analyzing inulin hydrolysis-products by thin layer chromatography indicated that this enzyme is endoinulinase (Figure 7). It is different from the inulinase from Streptomyces sp., the only purified and characterized inulinase

Table 3. Effects of amino acid modifying agents on inulinase activity.

\begin{tabular}{lcc}
\hline \multirow{2}{*}{ Amino acid modifying agent } & \multicolumn{2}{c}{ Relative activity $^{\mathrm{a}}(\%)$} \\
\cline { 2 - 3 } & $1 \mathrm{mM}$ & $10 \mathrm{mM}$ \\
\hline Control & 100 & 100 \\
Iodoacetamide (IAM) & 87.8 & 62.1 \\
$\begin{array}{l}\text { Ethylmethylaminopropyl-carbodiimide } \\
\text { (EDAC) }\end{array}$ & 101.5 & 98.7 \\
Phenylmethylsulfonyl-fluoride (PMSF) & 97.34 & 91.5 \\
N-Bromosuccimide (NBS) & 0 & $\mathrm{ND}^{\mathrm{b}}$ \\
\hline
\end{tabular}

${ }^{a}$ Relative activities were calculated in relation to the enzyme activity without pretreatment with amino acid modifying agents, which was considered to be $100 \%$; ${ }^{\mathrm{b}}$ Not done.

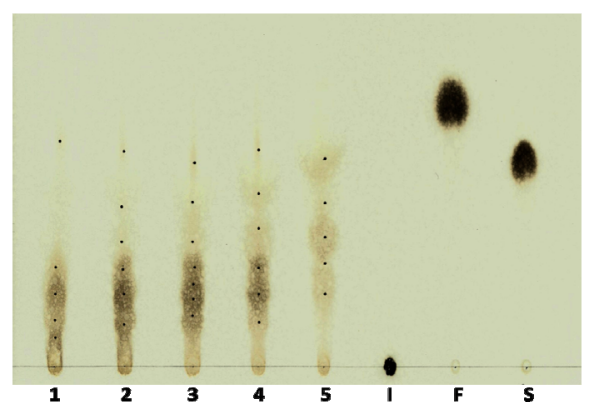

Figure 7. Thin layer chromatography of products of inulin hydrolysis by the purified enzyme. 1 to 5 , products from reaction times at $10,20,30,60$ and $90 \mathrm{~min}$, respectively; I, inulin; $F$, fructose; $S$, sucrose. from Streptomyces being reported so far, which is exoinulinase [16].

\section{Conclusion}

Streptomyces sp. CP01, a strong inulinase producer among Streptomyces, was isolated from Thai-soil. Under the optimal conditions, it produced about 3 folds higher inulinase activity than those of the other Streptomyces reported so far. The pure enzyme showed superior characteristics, including optimal activity at moderately high temperature and near neutral $\mathrm{pH}$ and retaining high activity at wide $\mathrm{pH}$-range when compared to those of inulinases from other microorganisms. Moreover, it has lower $K_{m}$ value for inulin, therefore this enzyme has high potential for industrial application.

\section{Acknowledgements}

This work was supported in part by CU.GRADUATE SCHOOL THESIS GRANT, Chulalongkorn University, Thailand.

\section{REFERENCES}

[1] E. J. Vandamme and D. G. Derycke, "Microbial Inulinases: Fermentation Process, Properties, and Applications," Advances in Applied Microbiology, Vol. 29, No. 1, 1983, pp.139-176. doi:10.1016/S0065-2164(08)70356-3

[2] I. Trojanova, V. Rada, L. Kokoska and E. Vlkova, "The Bifidogenic Effect of Taraxacum Officinale Root," Fitoterapia, Vol. 75, No. 7-8, 2004, pp. 760-763. doi:10.1016/j.fitote.2004.09.010

[3] A. K. Gupta and N. Kaur, "Fructan Storing Plants a Potential Source of High Fructose Syrups," Journal of Scientific and Industrial Research, Vol. 56, 1997, pp. 447452.

[4] S. E. Flemming and J. W. Grootwassink, "Preparation of High-Fructose Syrup from the Tubers of Jerusalem artichoke (Helianthus tuberosus L.)," Critical Reviews in Food Science and Nutrition, Vol. 12, No. 1, 1979, pp. 128. doi:10.1080/10408397909527271

[5] K. Szambelan, J. Nowak and Z. Czarnecki, "Use of Zymomonas mobilis and Saccharomyces cerevisiae Mixed with Kluyveromyces fragilis for Improved Ethanol Production from Jerusalem artichoke Tubers," Biotechnology Letters, Vol. 26, No. 10, 2004, pp. 845-848. doi:10.1023/B:BILE.0000025889.25364.4b

[6] N. Kango, "Production of Inulinase Using Tap Roots of Dandelion (Taraxacum officinale) by Aspergillus niger," Journal of Food Engineering, Vol. 85, No. 3, 2008, pp. 473-478. doi:10.1016/j.jfoodeng.2007.08.006

[7] R. S. Singh, R. Dhaliwal and M. Puri, "Production of Inulinase from Kluyveromyces marxianus YS-1 Using Root Extract of Asparagus racemosus," Process Biochemistry, Vol. 41, No. 7, 2006, pp. 1703-1707.

doi:10.1016/j.procbio.2006.03.005

[8] W. Gao, Y. Bo, Y. Liu, X. Zhang, J. Wang and L. An, 
"Characterization of Thermo-Stable Endoinulinase from a New Strain Bacillus smithii T7," Applied Biochemistry and Biotechnology, Vol. 157, No. 3, 2009, pp. 498-506. doi:10.1007/s12010-008-8313-1

[9] W. Wei, S. Wang, X. Zhu and W. Wan, "Isolation of a Mutant of Kluyveromyces sp. Y-85 Resistant to Catabolite Repression," Journal of Bioscience and Bioengineering, Vol. 87, No. 6, 1999, pp. 816-818. doi:10.1016/S1389-1723(99)80159-5

[10] X. Yu, N. Guo, Z. Chi, F. Gong, J. Sheng and Z. Chi, "Inulinase Overproduction by a Mutant of the Marine Yeast Pichia guilliermondii Using Surface Response Methodology and Inulin Hydrolysis," Biochemical Engineering Journal, Vol. 43, No. 3, 2009, pp. 266-271. doi:10.1016/j.bej.2008.10.018

[11] P. Selvakumar and A. Pandey, "Solid State Fermentation for the Synthesis of Inulinase from Staphylococcus sp. and Kluyveromyces marxianus," Process Biochemistry, Vol. 34, No. 8, 1999, pp. 851-855. doi:10.1016/S0032-9592(99)00008-4

[12] A. D. Sharma, S. Kainth and P. K. Gill, "Inulinase Production Using Garlic (Allium sativum) Powder as a Potential Substrate in Streptomyces sp.," Journal of Food Engineering, Vol. 77, No. 3, 2006, pp. 486-491. doi:10.1016/i.jfoodeng.2005.06.072

[13] P. K. Gill, A. D. Sharma, R. K. Harchand and P. Singh, "Effect of Media Supplements and Culture Conditions on Inulinase Production by an Actinomycete Strain," Bioresource Technology, Vol. 87, No. 3, 2003, pp. 359-362. doi:10.1016/S0960-8524(02)00262-6

[14] M. Hayakawa and H. Nonomura, "Humic Acid Vitamin Agar, a New Medium for the Selective Isolation of Soil Actinomycetes," Journal of Fermentation Technology, Vol. 65, No. 5, 1987, pp. 501-509. doi:10.1016/0385-6380(87)90108-7

[15] T. Kieser, M. J. Bibb, M. J. Buttner, K. F. Chater and D. A. Hopwood, "Practical Streptomyces Genetics," John Innes Foundation, Norwich, 2000.

[16] A. D. Sharma and P. K. Gill, "Purification and Characterization of Heat Stable Exo-Inulinase from Streptomyces sp.," Journal of Food Engineering, Vol. 79, No. 4, 2007, pp. 1172-1178. doi:10.1016/j.jfoodeng.2006.04.008

[17] M. Kataoka, K. Ueda, T. Kudo, T. Seki and T. Yoshida, "Application of the Variable Region in 16S rDNA to Create an Index for Rapid Species Identification in the Genus Streptomyces," FEMS Microbiology Letters, Vol. 151, No. 2, 1997, pp. 249-255. doi:10.1111/j.1574-6968.1997.tb12578.x

[18] W. Lingyun, W. Jianhua, Z. Xiaodong, T. Da, Y. L. Yang, C. G. Cai, F. Tianhua and Z. Fan, "Studies on the Extracting Technical Conditions of Inulin from Jerusalem artichoke Tubers," Journal of Food Engineering, Vol. 79, No. 3, 2007, pp. 1087-1093. doi:10.1016/i.jfoodeng.2006.03.028

[19] G. L. Miller, "Use of Dinitrosalicylic Acid Reagent for Determination of Reducing Sugars," Analytical Chemistry, Vol. 31, No. 3, 1959, pp. 426-428. doi: $10.1021 / \mathrm{ac} 60147 \mathrm{a} 030$

[20] O. H. Lowry, N. J. Rosebrough, A. L. Farr and R. J.
Randall, "Protein Measurement with the Folin Phenol Reagent," Journal of Biological Chemistry, Vol. 193, No. 1, 1951, pp. 267-275. doi:10.1038/227680a0

[21] U. K. Laemmli, "Cleavage of Structural Proteins during the Assembly of the Head of Bacteriophage T4," Nature, Vol. 227, No. 5259, 1970, pp. 680-685.

[22] A. Pandey, C. R. Soccol, P. Selvakumar, V. T. Soccol, N. Krieger and D. Jose, "Recent Developments in Microbial Inulinases, Its Production, Properties and Industrial Applications," Applied Biochemistry and Biotechnology, Vol. 81, No. 1, 1999, pp. 35-52. doi:10.1385/ABAB:81:1:35

[23] A. Pessoa Jr. and M. Vitolo, "Inulinase from Kluyveromyces marxianus: Culture Medium Composition and Enzyme Extraction," Brazilian Journal Chemical Engineering, Vol. 16, No. 6, 1999, pp. 237-245.

[24] M. L. Cazetta, P. M. M. Martins, R. Monti and J. Contiero, "Yacon (Polymnia sanchifolia) Extract as a Substrate to Produce Inulinase by Kluyveromyces marxianus var. bulgaricus," Journal of Food Engineering, Vol. 66, No. 3, 2005, pp. 301-305. doi:10.1016/i.jfoodeng.2004.03.022

[25] J. Sheng, Z. M. Chi, J. Li, L. M. Gao and F. Gong, "Inulinase Production by the Marine Yeast Cryptococcus aureus G7a and Inulin Hydrolysis by the Crude Inulinase," Process Biochemistry, Vol. 42, No. 5, 2007, pp. 805-811. doi:10.1016/j.procbio.2007.01.016

[26] E. M. Fawzi, "Comparative Study of Two Purified Inulinasees from Thermophile Thielavia terresttris NRRL 8126 and Mesophile Asspergillus foetidus NRRL 337 Grown on Chicorium intybus L.," Brazilian Journal of Microbiology, Vol. 42, No. 2, 2011, pp. 633-649. doi:10.1590/S1517-83822011000200028

[27] T. Nakamura, Y. Nagatomo, S. Hamada, Y. Nishino and K. Ohta, "Occurrence of Two Forms of Extracellular Endo-Inulinase from Aspergillus niger Mutant 817," Journal of Fermentation and Bioengineering, Vol. 78, No. 2, 1994, pp. 134-139. doi:10.1016/0922-338X(94)90251-8

[28] H. J. Kwon, S. J. Jeon, D. J. You, K. H. Kim, Y. K. Jeong, Y. H. Kim, Y. M. Kim and B. W. Kim, "Cloning and Characterization of an Exoinulinase from Bacillus polymyxa," Biotechnology Letters, Vol. 25, No. 2, 2003, pp. 155-159. doi:10.1023/A:1021987923630

[29] R. T. Kushi, R. Monti and J. Contiero, "Production, Purification and Characterization of an Extracellular Inulinase Came from Kluyveromyces marxianus var. bulgaricus," Journal of Industrial Microbiology and Biotechnology, Vol. 25, No. 2, 2000, pp. 63-69. doi:10.1038/sj.jim.7000032

[30] N. Kaur, M. Kaur, A. Gupta and R. Singh, "Properties of $\beta$-Fructosidases (Invertases and Inulinases) of Fusarium oxysporum Grown on Aqueous Extract of Cichorium intybus Roots," Journal of Chemical Technology and Biotechnology, Vol. 53, No. 3, 1992, pp. 279-284. doi:10.1002/jctb.280530308

[31] A. E. Cruz-Guerrero, I. Garcia-Pena, E. Barzana, M. Garcia-Garibay and L. Gomez-Ruiz, "Inulinase-Hyperproduction Strains of Kluyveromyces marxianus CDBB-L278: A Wild Inulinase Hyperproducing Strain," Journal 
of Fermentation and Bioengineering, Vol. 80, No. 2, 1995, pp. 159-163. doi:10.1016/0922-338X(95)93212-3

[32] R. S. Singh, B. S. Sooch and M. Puri, "Optimization of Medium and Process Parameters for the Production of Inulinase from a Newly Isolated Kluyveromyces marxianus YS-1," Bioresource Technology, Vol. 98, No. 13, 2007, pp. 2518-2525. doi:10.1016/j.biortech.2006.09.011

[33] F. Ertan, F. E. Sanal, A. C. Kaboglu, T. Aktac and E. Baker, "Some Propoties of Inulinase from Rhizoctonia solani," Journal of Biological Sciences, Vol. 5, No. 3, 2005, pp. 330-335. doi:10.3923/ibs.2005.330.334

[34] P. K. Gill, R. K. Manhas, J. Singh and P. Singh, "Purification and Characterization of Exoinulinase from Aspergillus fumigates," Applied Microbiology and Biotechnology, Vol. 117, No. 1, 2004, pp. 19-32.

[35] T. Nakamura, A. Shitara, S. Matsuda, T. Matsuo, M. Suiko and K. Ohta, "Production, Purification and Properties of an Endoinulinase of Penicillium sp. TN-88 That Liberates Inulotriose," Journal of Fermentation and Bioengineering, Vol. 84, No. 4, 1997, pp. 313-318. doi:10.1016/S0922-338X(97)89250-1

[36] J. Sheng, Z. M. Chi, F. Gong and J. Li, "Purification and Characterization of Extracellular Inulinase from a Marine Yeast Cryptococcus aureus G7a and Inulin Hydrolysis by the Purified Inulinase," Applied Biochemistry and Biotechnology, Vol. 144, No. 2, 2008, pp. 111-121. doi:10.1007/s12010-007-8025-y

[37] F. Gong, Z. M. Chi, J. Sheng, J. Li and X. H. Wang, "Purification and Characterization of Extracellular Inulinase from a Marine Yeast Pichia guilliermondii and Inulin Hydrolysis by the Purified Inulinase," Biotechnology and Bioprocess Engineering, Vol. 13, No. 5, 2008, pp. 533539. doi:10.1007/s12257-007-0177-7 